\title{
Kontribusi Keterampilan Membaca Pemahaman terhadap Keterampilan Pemecahan Masalah Matematika Kelas V SD Negeri Kecamatan IV Nagari, Kabupaten Sijunjung
}

\author{
Maifit Hendriani \\ STKIP Adzkia, Jl. Taratak Paneh No. 7 Kuranji, Padang, Sumatera Barat, Indonesia. \\ Email: maifithendriani92@gmail.com
}

\begin{abstract}
Abstrak
Keterampilan pemecahan masalah memiliki peranan penting dalam merumuskan konsep dan modal keberhasilan bagi siswa dalam menyelesaikan permasalahan matematika. Berdasarkan studi pendahuluan di sekolah dasar kelas lima di Kabupaten Nagari IV di Sijunjung, keterampilan pemecahan masalah matematika pada siswa relatif rendah, dari 10 pertanyaan keterampilan pemecahan masalah hanya $43 \%$ siswa yang berhasil menyelesaikannya. Penelitian bertujuan untuk mendeskripsikan Keterampilan membaca pemahaman dan keterampilan pemecahan masalah matematika serta kontribusi keterampilan membaca pemahaman terhadap keterampilan pemecahan masalah matematika siswa kelas V SD Negeri Kecamatan IV Nagari Kabupaten sijunjung. Jenis penelitian adalah penelitian korelasional. Populasi dalam penelitian ini adalah siswa kelas V se Kecamatan IV Nagari, Kabupaten Sijunjung. Teknik sampling yang digunakan adalah random sampling. Instrumen untuk mengumpulkan data adalah tes keterampilan membaca pemahaman dan keterampilan pemecahan masalah matematika. Teknik analisis yang digunakan adalah deskriptif dan korelasional. Hasil penelitian menunjukkan: 1) siswa kelas V SD Negeri Kecamatan IV Nagari memiliki keterampilan membaca pemahaman tinggi sebanyak $42,86 \%$ dan keterampilan pemecahan masalah matematika tinggi sebanyak $50,55 \%$; 2) terdapat kontribusi yang positif dan signifikan antara keterampilan membaca pemahaman terhadap keterampilan pemecahan masalah matematika dengan koefisien korelasi 0,646. Hal ini menunjukkan bahwa siswa yang memiliki keterampilan membaca pemahaman yang baik dipastikan dapat meningkatkan keterampilan pemecahan masalah matematika siswa tersebut.
\end{abstract}

Kata kunci: Keterampilan Membaca Pemahaman; Keterampilan Pemecahan Masalah

\begin{abstract}
Based on preliminary study in the fifth grade elementary school in IV Nagari district at Sijunjung, problem-solving skills of the mathematics at students is relatively low, from 10 questions of the problem-solving skill that contain in odd semester exam only $43 \%$ students can complete it. This research main to describe the comprehension reading skills and problem solving skills math, and contribution comprehension reading skills of the mathematical problem solving skills Elementary School fifth grade students in IV Nagari district, at Sijunjung. This research is a correlational study. The population in this study is a fifth grade students throughout the District IV Nagari, Sijunjung. The sampling technique used random sampling. Instruments for collecting data is comprehension reading skill test, creativity and problem solving skills of mathematics. The analysis technique used descriptive and correlational. The results show: 1) Elementary School fifth grade students in IV Nagari district have high comprehension reading skills is $42.86 \%$ and high math problem-solving skills is 50.55\%; 2) there is a significant and positive contributiont correlation between reading comprehension skills to the math problem solving skills with a correlation coefficient 0.646
\end{abstract}

Keywords: Problem Solving Skills; Reading Comprehension skills 
Maifit Hendriani

\section{Pendahuluan}

Keterampilan pemecahan masalah merupakan keterampilan dasar dalam pendidikan matematika yang harus dimiliki seseorang untuk digunakan diberbagai bidang dalam kehidupan sehari-hari (Kaya dkk., 2014 : 295). Oleh karena itu, standar kemampuan tersebut dimasukkan ke dalam kurikulum sekolah. Pemecahan masalah merupakan bagian dari kurikulum matematika yang sangat penting karena dalam proses pembelajaran maupun penyelesaian, siswa dimungkinkan memperoleh pengalaman menggunakan pengetahuan serta keterampilan yang sudah dimiliki untuk diterapkan dalam pemecahan masalah ( Nurdalillah., dkk, 2010 : 109). Dalam pembelajaran matematika keterampilan pemecahan masalah berperan dalam merumuskan konsep dan modal keberhasilan bagi siswa dalam menyelesaikan permasalahan matematika. Keterampilan pemecahan masalah melatih individu untuk mengatasi masalah kehidupan nyata (Memnun., dkk, 2012 : 172).

Permasalahannya di kelas V SD Negeri Kecamatan IV Nagari Kabupaten Sijunjung yang terdiri dari 7 sekolah, keterampilan siswa dalam memecahkan masalah matematika masih tergolong rendah, hal ini berdasarkan hasil ujian ulangan matematika semester ganjil siswa yang terdiri dari 40 butir soal. 10 butir merupakan soal pemecahan masalah, dari 10 soal tersebut hanya $43 \%$ siswa yang berhasil menyelesaikannya.

Hasil wawancara dengan guru kelas $\mathrm{V}$ SD Negeri Kecamatan IV Nagari Kabupaten Sijunjung, ketika menyelesaikan soal pemecahan masalah matematika siswa masih banyak bertanya tentang apa yang dimaksudkan dari soal tersebut, apa saja yang diketahui di dalam soal, dan langkah apa yang harus dilakukan untuk menyelesaikan soal. Guru juga menyatakan bahwa, siswa dalam menyelesaikan permasalahan matematika mampu mengerjakan seperti apa yang telah dicontohkan sebelumnya, tetapi jika permasalahan yang dihadapi sedikit berbeda penyajiannya dengan contoh sebelumnya siswa merasa kesulitan untuk menyelesaikannya. Selain itu siswa juga mengalami kesulitan dalam mengaitkan masalah sehari-hari ke dalam bahasa matematika, contohnya dalam materi perkalian siswa mampu dengan mudah mencari penyelesaian dari suatu soal perkalian tetapi mengalami kesulitan apabila soal tersebut diubah ke bentuk soal cerita.

Hal yang senada terdapat dalam laporan Programme for International Student Assessment (PISA) matematika tahun 2009 (dalam Wijaya, 2012:1), diperoleh hasil bahwa, sekitar sepertiga siswa Indonesia (yaitu 33,1\%) hanya bisa mengerjakan soal jika pertanyaan dari soal kontekstual diberikan secara eksplisit serta semua data yang dibutuhkan untuk mengerjakan soal diberikan secara tepat, dan hanya $0,1 \%$ siswa Indonesia yang mampu mengembangkan dan mengerjakan pemodelan matematika yang menuntut keterampilan berpikir. Sejalan dengan itu Erdogan juga menyatakan (2013:1) dalam jurnalnya, ".... Non-routine problem solving strategies were quite poor and inflexible". Strategies keterampilan pemecahan masalah tidak rutin siswa SD sangat miskin dan tidak fleksibel. Berdasarkan masalah di atas, maka dilakukan penelitian untuk mengetahui penyebab rendahnya keterampilan pemecahan masalah matematika siswa kelas V SD.

Keberhasilan dalam memecahkan masalah matematika sangat berkaitan dan bergantung pada pengembangan keterampilan membaca tingkat tinggi dalam hal ini adalah keterampilan membaca pemahaman. Kemampuan bahasa 
memiliki nilai prediktif yang kuat untuk keterampilan matematika (Zhang, J., dkk, 2017 : 14). Keterampilan membaca pemahaman merupakan kemampuan seseorang bekerja dalam motorik dan mengoptimalkan fungsi mental yang berhubungan dengan kegiatan kognitif untuk dapat memahami isi bacaan secara detail serta dapat memaknai bacaan secara cepat dan tepat ( Windari F., dkk 2014:26). Seseorang dikatakan paham jika dapat mengubah suatu informasi yang ada dalam pikirannya kedalam bentuk lain (Hasibuan dkk, 2014: 38). Memahami masalah matematika tidak hanya memahami kata-kata dan arti dari kalimat, tetapi juga harus mampu menerjemahkan frase bahasa inggris dan kalimat ke dalam ekspresi dan persamaan matematika.

Menurut Polya (dalam Suherman dkk, 2003 : 91), fase pertama untuk menyelesaikan suatu permasalahan adalah memahami masalah, tanpa adanya pemahaman terhadap masalah yang diberikan, siswa tidak mungkin mampu menyelesaikan masalah tersebut dengan benar. Hal ini sejalan dengan hasil penelitian yang dilakukan Ozsoy dkk (2015) yang dijelaskan dalam jurnalnya bahwa, " Problem solving skills varied according to reading level". Ozsoy dkk menemukan bahwa, keterampilan pemecahan masalah matematika dipengaruhi oleh tingkat membaca seseorang. Ini berarti salah satu faktor utama dalam pemecahan suatu masalah adalah keterampilan memahami bacaan (soal cerita).

Dalman (2014) menyatakan bahwa memahami bacaan merupakan keterampilan membaca pada urutan yang lebih tinggi, pembaca tidak lagi dituntut bagaimana melafalkan huruf dengan benar dan merangkaikan setiap bunyi menjadi bentuk kata, frasa, dan kalimat. Tetapi, di sini seseorang dituntut untuk memahami isi bacaan yang dibacanya. Somadayo
(2011:11) menyatakan bahwa, seseorang dikatakan memahami bacaan secara baik apabila memiliki kemampuan sebagai berikut: (1) Kemampuan menangkap arti kata dan ungkapan yang digunakan penulis, (2) Kemampuan menangkap makna tersurat dan makna tersirat, dan (3) kemampuan membuat simpulan.

Berdasarkan permasalahan dan uraian di atas, peneliti tertarik untuk mengetahui Kontribusi Keterampilan Membaca Pemahaman terhadap Keterampilan Pemecahan Masalah Matematika di Kelas V Sekolah Dasar Negeri Kecamatan IV Nagari Kabupaten Sijunjung.

Metode Penelitian

Penelitian ini adalah penelitian kuantitatif dengan jenis penelitian korelasional. Arikunto (2000:326) menyatakan, penelitian korelasional merupakan penelitian yang dimaksudkan untuk mengetahui ada tidaknya hubungan antara dua atau beberapa variabel. Analisis yang digunakan adalah analisis deskriptif dan inferensial untuk menggambarkan kondisi variabel sebagaimana adanya tanpa memberikan perlakuan, dan menarik generalisasi dari sampel terhadap populasi. Penelitian ini menempatkan satu kelompok variabel bebas keterampilan membaca pemahaman dan keterampilan pemecahan masalah matematika sabagai variabel terikat.

Populasi dalam penelitian ini adalah siswa kelas V SDN kecamatan IV nagari kabupaten Sijunjung yang berjumlah sebanyak 146 siswa yang tersebar dari 7 sekolah. Sampel penelitian berjumlah 91 siswa yang tersebar dari 6 sekolah, diambil dengan menggunakan teknik simple random sampling.

Data dikumpul menggunakan instrumen tes keterampilan pemecahan masalah matematika dan tes keterampilan membaca pemahaman, yang bersumber dari siswa kelas V SDN kecamatan IV 
Maifit Hendriani

nagari, kabupaten Sijunjung. Tes yang digunakan untuk mengukur keterampilan pemecahan masalah matematika adalah tes essay sebanyak 10 soal. Penilaian dalam instrumen ini dilakukan dengan cara penskoran menggunakan rubrik. Rubrik penilaian tes keterampilan pemecahan masalah matematika siswa dapat di lihat pada Tabel 1.

Tabel 1. Rubrik Penilaian Tes Keterampilan Pemecahan Masalah Matematika

\begin{tabular}{|c|c|c|c|}
\hline Skor & $\begin{array}{l}\text { Mengidentifikasi Unsur- } \\
\text { unsur yang diketahui, } \\
\text { ditanyakan dan kecukupan } \\
\text { unsur-unsur diperlukan }\end{array}$ & $\begin{array}{l}\text { Menentukan strategi yang } \\
\text { tepat dalam menyelesaikan } \\
\text { permasalahan }\end{array}$ & \begin{tabular}{|l|l|} 
Menyelesaikan \\
soal yang \\
muncul
\end{tabular} \\
\hline 0 & Tidak ada jawaban & Tidak ada jawaban & $\begin{array}{ll}\text { Tidak } & \text { ada } \\
\text { jawaban } & \end{array}$ \\
\hline 1 & $\begin{array}{l}\text { Ada sedikit jawaban, } \\
\text { namun belum tepat untuk } \\
\text { mengidentifikasi unsur- } \\
\text { unsur yang diketahui, } \\
\text { ditanyakan, dan kecukupan } \\
\text { unsur yang diperlukan }\end{array}$ & $\begin{array}{l}\text { Ada sedikit jawaban, } \\
\text { namun belum tepat dalam } \\
\text { menentukan strategi yang } \\
\text { tepat dalam menyelesaikan } \\
\text { masalah. }\end{array}$ & $\begin{array}{l}\text { Adar sedikit } \\
\text { jawaban, namun } \\
\text { belum tepat } \\
\text { untuk } \\
\text { menyelesaikan } \\
\text { soal yang } \\
\text { muncul }\end{array}$ \\
\hline 2 & $\begin{array}{l}\text { Ada jawaban, namun } \\
\text { terdapat sedikit kesalahan } \\
\text { dalam mengidentifikasi } \\
\text { unsur-unsur yang diketahui, } \\
\text { ditanyakan, dan kecukupan } \\
\text { unsur yang diperlukan. }\end{array}$ & $\begin{array}{l}\text { Ada jawaban, namun } \\
\text { terdapat sedikit kesalahan } \\
\text { dalam menentukan strategi } \\
\text { yang tepat dalam } \\
\text { menyelesaikan } \\
\text { permasalahan }\end{array}$ & $\begin{array}{l}\text { Ada jawaban, } \\
\text { namun terdapat } \\
\text { sedikit } \\
\text { kesalahan } \\
\text { dalam } \\
\text { menyelesaikan } \\
\text { soal yang } \\
\text { muncul. }\end{array}$ \\
\hline 3 & $\begin{array}{l}\text { Jawaban benar dan tepat } \\
\text { dalam mengidentifikasi } \\
\text { unsur-unsur yang diketahui, } \\
\text { ditanyakan, dan kecukupan } \\
\text { unsur yang diperlukan. }\end{array}$ & $\begin{array}{l}\text { Jawaban benar dan tepat } \\
\text { dalam menentukan strategi } \\
\text { yang tepat dalam } \\
\text { menyelesaikan } \\
\text { permasalahan. }\end{array}$ & $\begin{array}{l}\text { Jawaban benar } \\
\text { dan tepat dalam } \\
\text { menyelesaikan } \\
\text { soal yang } \\
\text { muncul }\end{array}$ \\
\hline & Skor Maks. 3 & Skor Maks. 3 & Skor Maks. 3 \\
\hline
\end{tabular}

Sumber : Diadaptasi dari Fauzan (2012:35)

Tes yang digunakan untuk mengukur keterampilan membaca pemahaman siswa adalah tes objektif sebanyak 40 butir. Penilaian dalam instrumen tes ini dilakukan dengan cara memberi nilai 1 untuk butir soal yang dijawab benar dan nilai 0 untuk butir soal yang dijawab salah. Data yang diperoleh dianalisis dengan menggunakan rumus Pearson Product Moment Correlation I dengan program SPSS for windows version 16.0 .

\section{Hasil dan Pembahasan} Keterampilan Membaca Pemahaman

Berdasarkan data hasil penelitian, diperoleh data tentang keterampilan membaca pemahaman siswa kelas V SD Negeri Kecamatan IV Nagari Kabupaten Sijunjung dengan skor maksimum 17 dan skor minimum 5 . Nilai rata-rata 10, 88, standar deviasi 3,119 dan median 11 . Paparan distribusi frekuensi menggunakan aturan Sturges. Data dari 91 responden menunjukkan banyak kelas interval menjadi 7 (tujuh); dan lebar kelas interval 2. penyajian mengenai distribusi frekuensi dan distribusi kecenderungan variabel dapat di lihat pada Tabel 2 dan Tabel 3.

Tabel 2. Distribusi Frekuensi Skor

Variabel Keterampilan Membaca Pemahaman

\begin{tabular}{|c|c|c|c|}
\hline \multirow{2}{*}{ No } & Interval & \multicolumn{2}{|c|}{ Frekuensi } \\
\cline { 3 - 4 } & & Absolut & Relatif \% \\
\hline 1 & $4,5-6,5$ & 9 & 9,89 \\
\hline 2 & $6,5-8,5$ & 12 & 13,18 \\
\hline 3 & $8,5-10,5$ & 21 & 23,07 \\
\hline 4 & $10,5-12,5$ & 19 & 20,87 \\
\hline 5 & $12,5-14,5$ & 19 & 20,87 \\
\hline 6 & $14,5-16,5$ & 8 & 8,79 \\
\hline 7 & $16,5-18,5$ & 3 & 3,29 \\
\hline \multicolumn{2}{|c|}{ Jumlah } & 91 & 100 \\
\hline
\end{tabular}

Berikut penyajian bentuk histogram data keterampilan membaca pemahaman.

KCMP

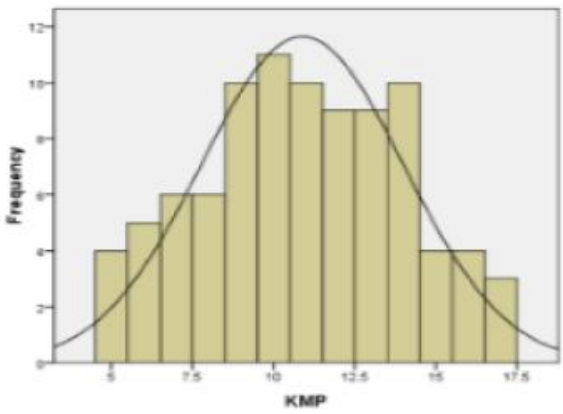

Gambar 1. Distribusi Frekuensi Skor Variabel Keterampilan Membaca 
ISSN 2548-9119

Pemahaman

Tabel 3. Distribusi Kecenderungan Variabel Keterampilan Membaca Pemahaman

\begin{tabular}{|c|c|c|c|c|}
\hline \multirow[t]{2}{*}{ No } & \multirow[t]{2}{*}{ Skor } & \multicolumn{2}{|c|}{ Frekuensi } & \multirow[t]{2}{*}{ Kategori } \\
\hline & & Absolut & Relatif \% & \\
\hline 1 & $x \geq 11,33$ & $\overline{39}$ & 42,86 & Tinggi \\
\hline 2 & $11,33>x \geq 8,5$ & 31 & 34,07 & Cukup \\
\hline 3 & $8,5>X \geq 5,67$ & 17 & 18,68 & Kurang \\
\hline 4 & $X<5,67$ & 4 & 4,40 & Rendah \\
\hline & Jumlah & 91 & 100 & \\
\hline
\end{tabular}

Dari Tabel 3 dapat disimpulkan bahwa siswa kelas V SDN Kecamatan IV Nagari Kabupaten Sijunjung yang mempunyai keterampilan membaca pemahaman tinggi sebanyak 39 siswa atau 42,86\%, keterampilan membaca pemahaman cukup tinggi sebanyak 31 atau $34,07 \%$, keterampilan membaca pemahaman kurang tinggi sebanyak 17 siswa atau $18,86 \%$ dan keterampilan membaca pemahaman rendah sebanyak 4 siswa atau $4,40 \%$. Dengan demikian dapat disimpulkan bahwa siswa kelas $\mathrm{V}$ SDN Kecamatan IV Nagari Kabupaten Sijunjung cenderung memiliki keterampilan membaca pemahaman tinggi.

\section{Keterampilan Pemecahan Masalah Matematika}

Berdasarkan data hasil penelitian, diperoleh data tentang keterampilan pemecahan masalah matematika siswa kelas V SD Negeri Kecamatan IV Nagari Kabupaten Sijunjung dengan skor maksimum 63 dan skor minimum 8 . Nilai rata-rata 39,70, standar deviasi 15,225 dan median 42. Paparan distribusi frekuensi menggunakan aturan Sturges. Data dari 91 responden menunjukkan banyak kelas interval menjadi 7 (tujuh); dan lebar kelas interval 7. penyajian mengenai distribusi frekuensi dan distribusi kecenderungan variabel dapat di lihat pada Tabel 4 dan Tabel 5.

Tabel 4. Distribusi Frekuensi Skor

Variabel Keterampilan Pemecahan Masalah Matematika

\begin{tabular}{|c|c|c|c|}
\hline \multirow{2}{*}{ No } & \multirow{2}{*}{ Interval } & \multicolumn{2}{|c|}{ Frekuensi } \\
\cline { 3 - 4 } & & Absolut & Relatif \% \\
\hline 1 & $7,5-14,5$ & 5 & 5,5 \\
\hline 2 & $14,5-21,5$ & 7 & 7,7 \\
\hline 3 & $21,5-28,5$ & 14 & 14,0 \\
\hline 4 & $28,5-35,5$ & 11 & 12,1 \\
\hline 5 & $35,5-42,5$ & 10 & 11,0 \\
\hline 6 & $42,5-56,5$ & 28 & 30,8 \\
\hline 7 & $56,5-63,5$ & 16 & 17,6 \\
\hline & Jumlah & 91 & 100 \\
\hline
\end{tabular}

Berikut penyajian bentuk histogram data keterampilan pemecahan masalah matematika.

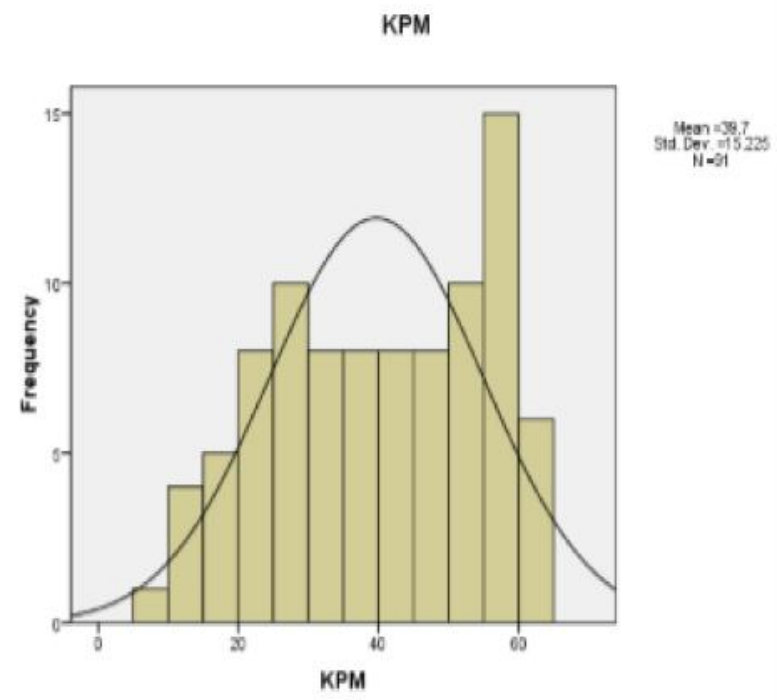

Gambar 2. Distribusi Frekuensi Skor Variabel Keterampilan Pemecahan

Masalah Matematika 
Maifit Hendriani

Tabel 5. Distribusi Kecenderungan Variabel Keterampilan Pemecahan Masalah Matematika

\begin{tabular}{|c|c|c|c|c|}
\hline \multirow{2}{*}{ No } & Skor & \multicolumn{2}{|c|}{ Frekuensi } & \multirow{2}{*}{ Kategori } \\
\cline { 3 - 4 } & & Absolut & Relafif \% & \\
\hline 1 & $X \geq 42$ & 46 & 50,55 & Tinggi \\
\hline 2 & $42>X \geq 31,5$ & 13 & 14,23 & Cukup \\
\hline 3 & $31,5>X \geq 21$ & 21 & 23,07 & Kurang \\
\hline 4 & $X<21$ & 11 & 12,08 & Rendah \\
\hline \multicolumn{2}{|c|}{ Jumlah } & 91 & 100 & \\
\hline
\end{tabular}

Dari Tabel 5 dapat disimpulkan bahwa siswa kelas V SDN Kecamatan IV Nagari Kabupaten Sijunjung yang mempunyai keterampilan pemecahan masalah matematika tinggi sebanyak 46 siswa atau $50,55 \%$, keterampilan pemecahan masalah matematika cukup tinggi sebanyak 13 siswa atau 14,23\%, keterampilan pemecahan masalah matematika kurang tinggi sebanyak 21 siswa atau $23,07 \%$ dan keterampilan pemecahan masalah matematika rendah sebanyak 11 siswa atau $12,08 \%$. Dengan demikian dapat disimpulkan bahwa siswa kelas V SDN Kecamatan IV Nagari Kabupaten Sijunjung cenderung memiliki keterampilan pemecahan masalah matematika tinggi.

\section{Kontribusi Keterampilan Membaca Pemahaman Terhadap Keterampilan pemecahan Masalah Matematika}

Hipotesisnya adalah : terdapat kontribusi yang positif antara keterampilan membaca pemahaman $\left(\mathrm{X}_{1}\right)$ dengan keterampilan pemecahan masalah matematika $(Y)$.

a) Persamaan regresi

$$
\hat{Y}=5,40 \mid 5+3,153 X_{1}
$$

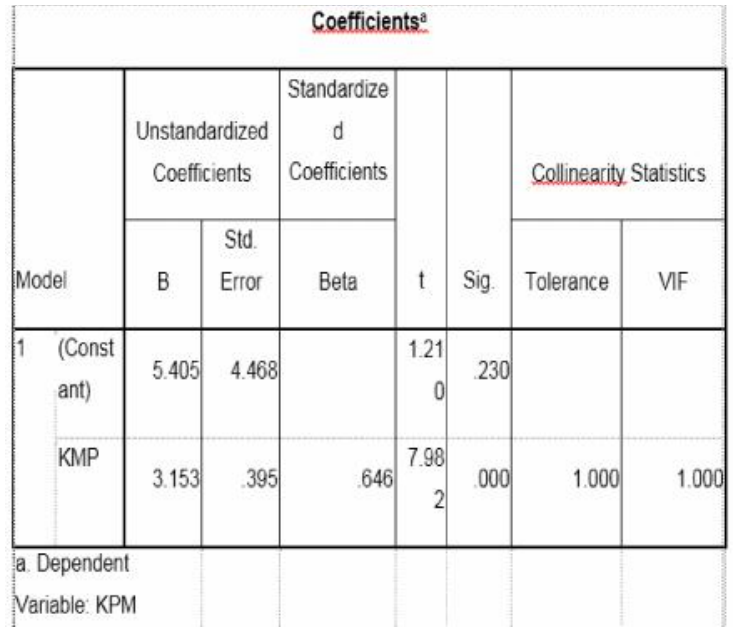

b) Uji linieritas

Hipotesis :

$\mathrm{H}_{0}=$ persamaan regresi sederhana $(\mathrm{V}$ $\left.=5,405+3,153 x_{1}\right)$ linier

$\mathrm{H}_{1}=$ persamaan regresi sederhana $(\mathrm{v}$ $=5,405+3,153 x_{1}$ ) tidak linier

Jika nilai sig $, 0,05$ maka $\mathrm{H}_{0}$ ditolak dan jika nilai sig ${ }_{d^{\prime \prime}} 0,05$ maka $\mathrm{H}_{0}$ diterima diperoleh nilai sig $0,000<0,05$ maka dapat disimpulkan bahwa Ho diterima atau persamaan regresi sederhana $(v=5,405+$ $3,153 x_{1}$ ) adalah linier.

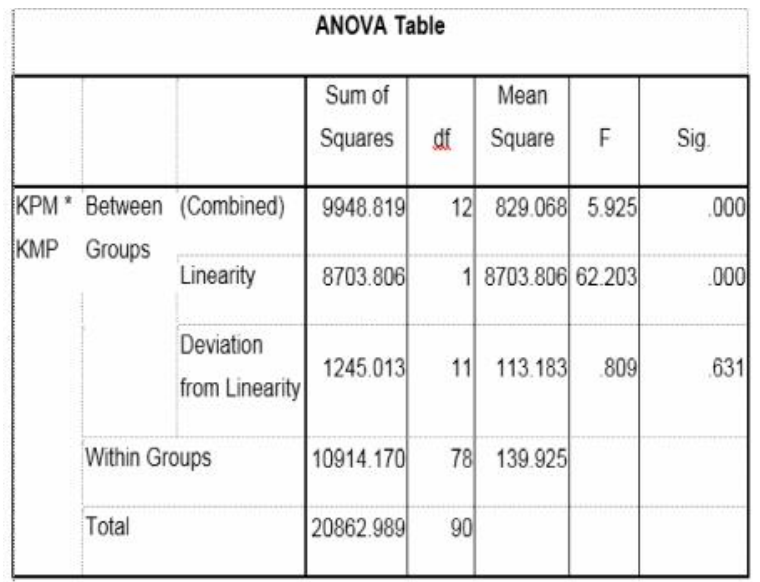

c) Uji signifikansi regresi sederhana Hipotesis :

$\mathrm{H}_{0}$ : persamaan regresi sederhana ( $\mathrm{V}$ $\left.=5,405+3,153 x_{1}\right)$ signifikan $\mathrm{H}_{1}=$ persamaan regresi sederhana $(\mathrm{v}$ $\left.=5,405+3,153 x_{1}\right)$ tidak signifikan Jika $\mathrm{F}_{\text {hitung }<} \mathrm{F}_{\text {tabel }}$ maka $\mathrm{H}_{0}$ ditolak dan jika $\mathrm{F}_{\text {hitung e }} \mathrm{F}_{\text {tabel }}$ maka $\mathrm{H}_{0}$ diterima. Diperoleh 
$F_{\text {hitung }(63,708) \text { e" }} F_{\text {tabel }(3,96) \text {, maka dapat }}$ disimpulkan bahwa $\mathrm{H}_{0}$ diterima atau persamaan regresi sederhana ( $\mathrm{v}=5,405$ $+3,153 x_{1}$ ) adalah signifikan. Data $F_{\text {tabel }}$ diperoleh dari df (1.89).

\begin{tabular}{|l|r|r|r|r|r|}
\hline \multicolumn{7}{|c|}{ ANOVA $^{\mathrm{b}}$} \\
\hline Model & Sum of Squares & df & Mean Square & $\mathrm{F}$ & Sig. \\
\hline $1 \quad$ Regressio \\
$\mathrm{n}$
\end{tabular}

a. Predictors: (Constant), KMP

b. Dependent Variable: KPM

\section{d) Koofisien determinan}

Berdasarkan hasil perhitungan dengan bantuan program SPSS version 16 diperoleh $r^{2} Y$ I sebesar 0,417 . Nilai tersebut berarti $41,7 \%$ perubahan pada variabel keterampilan pemecahan masalah mamatika dipengaruhi oleh keterampilan membaca pemahaman. Sedangkan sisanya dijelaskan oleh variabel lain.

Model Summary

\begin{tabular}{|l|r|r|r|r|}
\hline Model & \multicolumn{1}{|c|}{$\mathrm{R}$} & R Square & \multicolumn{1}{c|}{$\begin{array}{c}\text { Adjusted R } \\
\text { Square }\end{array}$} & $\begin{array}{c}\text { Std. Error of the } \\
\text { Estimate }\end{array}$ \\
\hline 1 & $646^{\circ}$ & .417 & 411 & 11.688 \\
\hline
\end{tabular}
a. Predictors: (Constant), KMP
b. Dependent Variable: KPM

e) Koefisien korelasi

Berdasarkan hasil perhitungan didapat bahwa kontribusi keterampilan membaca pemahaman terhadap keterampilan pemecahan masalah matematika bernilai 0,646. ini artinya kontribusi keterampilan membaca pemahaman terhadap keterampilan pemecahan masalah matematika kuat dan searah. Nilai "+" (positif) artinya apabila keterampilan membaca pemahaman makin tinggi, maka keterampilan pemecahan masalah matematika siswa akan semakin tinggi.

f) Kesimpulan

Terdapat kontribusi yang positif dan signifikan antara keterampilan membaca pemahaman dan keterampilan pemecahan masalah matematika.

Berdasarkan hasil penelitian di kelas $\mathrm{V}$ SDN Kecamatan IV Nagari, Kabupaten Sijunjung ditemukan bahwa koefisien korelasi keterampilan membaca pemahaman dengan keterampilan pemecahan masalah matematika tergolong kuat. Selanjutnya, keterampilan membaca pemahaman memberikan kontribusi yang signifikan terhadap keterampilan pemecahan masalah matematika. Hal ini menunjukkan bahwa keterampilan pemecahan masalah matematika siswa dipengaruhi oleh keterampilan membaca pemahaman mereka. Oleh karena itu keterampilan membaca pemahaman harus mendapatkan perhatian yang lebih dari siswa dan guru kelas V SDN Kecamatan IV Nagari, Kabupaten Sijunjung.

Kontribusi keterampilan membaca pemahaman terhadap keterampilan pemecahan masalah matematika memiliki persamaan regresi sederhana $v=5,405+$ $3,153 \times 1$ hal ini menunjukkan bahwa pada saat keterampilan membaca pemahaman belum memberikan pengaruh terhadap keterampilan pemecahan masalah matematika, nilai keterampilan pemecahan masalah matematika telah ada sebesar 5,405 pada saat keterampilan membaca pemahaman memberikan satu nilai, maka nilai keterampilan pemecahan masalah matematika akan berubah sebesar 5,405 $+3,153$ (1) oleh karena itu, semakin tinggi keterampilan membaca pemahaman yang dimiliki siswa, maka semakin tinggi keterampilan pemecahan masalah matematika mereka. 
Maifit Hendriani

Temuan penelitian ini sejalan dengan hasil penelitian yang dilakukan Ozsoy dkk (2015) yang dijelaskan dalam jurnalnya bahwa, "Problem solving skills varied according to reading level". Ozsoy dkk menemukan bahwa, keterampilan pemecahan masalah matematika dipengaruhi oleh tingkat membaca seseorang. Hasil penelitian juga sesuai dengan hasil penelitian Yudiani dkk yang menyatakan bahwa terdapat kontribusi yang signifikan kemampuan membaca pemahaman terhadap prestasi belajar dalam menyelesaikan soal cerita pelajaran matematika pada kelas V SD gugus IV Kuta.

Menurut Maharani dkk (2018: 138), keterampilan membaca pemahaman merupakan kegiatan yang bertujuan agar pembaca dapat mengetahui keseluruhan isi bahan bacaan. Apabila seseorang dapat menjawab apa yang ditanyakan tentang isi bacaan yang telah dibacanya, berarti ia telah memahami bacaan yang dibaca. Seseorang yang paham apa yang dibaca akan dapat memproduksi isi bacaan bila diperlukan.

Maharani dkk menyatakan bahwa masalah harus diterjemahkan ke dalam bahasa pembaca dengan kata lain masalah tersebut dipahami oleh pembaca atau memerlukan keterampilan membaca pemahaman.

Berdasarkan hasil penelitian dan beberapa pendapat ahli di atas, dapat disimpulkan bahwa keterampilan membaca pemahaman siswa harus ditingkatkan agar keterampilan pemecahan masalah matematika meningkat.

Sebagaimana pernyataan yang telah diuraikan dalam latar belakang penelitian bahwa keterampilan membaca pemahaman memiliki berkontribusi terhadap keterampilan pemecahan masalah matematika, maka pernyataan tersebut telah dibuktikan dengan hasil penelitian. Hasil penelitian menunjukkan bahwa keterampilan membaca pemahaman memberikan kontribusi yang positif dan signifikan terhadap keterampilan pemecahan masalah matematika. Hal ini ditunjukkan melalui hasil analisis regresi sederhana, diperoleh nilai Fhitung 63,708. harga Fhitung jauh lebih besar dari nilai Ftabel $(F(0,05 ; 89)=3,96)$. sedangkan koefisien determinasi sebesar 0,417 menunjukkan 41,7\% keterampilan pemecahan masalah matematika dapat dijelaskan melalui keterampilan membaca pemahaman. Artinya semakin tinggi keterampilan membaca pemahaman siswa, semakin tinggi pula keterampilan pemecahan masalah matematika siswa. Keterampilan membaca pemahaman merupakan satu diantara sekian banyak faktor yang memberikan sumbangan terhadap keterampilan pemecahan masalah matematika siswa kelas V SDN Kecammatan IV Nagari, Kabupaten Sijunjung. Semakin tinggi keterampilan membaca pemahaman siswa, maka semakin tinggi keterampilan pemecahan masalah matematika mereka. Hal ini disebabkan keterampilan membaca pemahaman dapat membantu siswa memahami masalah sampai pada hal yang sangat detail. Jadi, rendahnya nilai keterampilan pemecahan masalah matematika siswa bisa ditingkatkan dengan meningkatkan keterampilan membaca pemahaman mereka.

\section{Kesimpulan}

Terdapat kontribusi yang positif dan signifikan antara keterampilan membaca pemahaman terhadap keterampilan pemecahan masalah matematika siswa kelas V SDN Kecamatan IV Nagari Kabupaten Sijunjung. Kekuatan kontribusi tersebut ditunjukkan melalui koefisien korelasi sebesar 0,646 dan nilai koefisien determinasi sebesar 0,417, atau 
keterampilan pemecahan masalah matematika $41,7 \%$ dapat dijelaskan oleh variabel keterampilan membaca pemahaman.

Hasil penelitian ini menjelaskan bahwa keterampilan membaca pemahaman berkontribusi terhadap keterampilan pemecahan masalah matematika siswa kelas V SD Negeri Kecamatan IV Nagari, Kabupaten Sijunjung. Hal ini menunjukkan bahwa keterampilan membaca pemahaman merupakan faktor yang dapat memberikan kontribusi terhadap keterampilan pemecahan masalah matematika. Siswa yang memiliki keterampilan membaca pemahaman yang baik dipastikan dapat meningkatkan keterampilan pemecahan masalah matematika siswa tersebut. Oleh karena itu, usaha peningkatan keterampilan membaca pemahaman perlu diupayakan semaksimal mungkin.

Untuk meningkatkan keterampilan membaca pemahaman siswa, dapat dilakukan beberapa cara berikut: (1) Pihak sekolah menyediakan kamus dan buku- buku bacaan/teks di dalam kelas sehingga siswa mudah mencari makna dari kata-kata sulit yang ditemukan dalam bacaan/teks. (2) Guru meminta siswa membaca dan mencari arti kata-kata sulit, kemudian siswa mencari arti kata-kata sulit tersebut di dalam kamus dan berbagai sumber lain. Kebiasaan membaca yang dilakukan siswa akan membantu mereka dalam memahami bacaan tersebut sehingga ketika siswa tahu mengenai suatu karangan, siswa tersebut telah memperoleh pengetahuan tentang bacaan.

Apabila dalam proses belajar mengajar siswa memilki keterampilan membaca pemahaman yang tinggi. Maka siswa tersebut akan lebih mudah untuk menerapkan keterampilan pemecahan masalah matematika. Bagi peneliti selanjutnya diharapkan dapat terdorong untuk melakukan penelitian sejenis lebih lanjut. Disarankan untuk meneliti variabel lain yang berhubungan dan ikut mempengaruhi keterampilan pemecahan masalah matematika.

\section{Daftar Pustaka}

Arikunto, Suharsimi. 2006. Manajemen Penelitian. Jakarta: Rineka Cipta

Dalman. 2014. Keterampilan Membaca. Jakarta: Rajawali Pers

Erdogan, Abdulkadir. 2013. Turkish Primary School Students' Strategies In Solving A Nonroutine Mathematical Probelm and Some Impilcations for The Curriculum Design and Implementation. http://content.ebscohost.com. Di akses 27 Februari 2016

Hasibuan, Irwan, dan Mirna. 2014. Penerapan Metode Penemuan Terbimbing pada Pembelajaran Matematika kelas XI IPA SMAN 1 Lubuk Alung: Jurnal Pendidikan Matematika. Volume 3 Nomor 1 : hlm. 38-44

Kaya, D., D. Izgiol, dan C. Kesan. 2014. The Investigation of Elemntary Mathematics Teacher Candidates Problem Solving Skill According to Various Variables: International Electronic Journal of Elementary Education. Volume 6 Nomor 2 (Januari 2014): hlm. 295-314 
Maifit Hendriani

Maharani, D.P.A., Harris, E.T., Emidar. 2018. Kontribusi Keterampilan Membaca Pemahaman terhadap Keterampilan Menulis Teks Eksposisi Siswa Kelas VIII SMP Negeri 25 Padang: ejournal.unp.ac.id. Volume 7. Nomor 3. hlm 137-143

Memnun, D.S., Lynn. C. Hart, dan Recai Akkaya. 2012. A Research on the Mathematical Problem Solving Beliefs of Mathematics, Science and Elementary Pre-Service Teachers in Turkey in term of Different Variables: International Journal of Humanities an Social Science. Volume. 2 Nomor. 24, hlm. 172-184

Nurdalilah, S. E. Armanto, dan Dian. 2010. Perbedaan Kemampuan Penalaran Matematika dan Pemecahan Masalah pada Pembelajaran Berbasis Masalah dan Pembelajaran Konvensional di SMA Negeri 1 Kualuh Selatan. Jurnal Pendidikan Matematika PARADIKA. Volume. 6 Nomor. 2, hlm. 109 -119

Ni Made Yudiani, A.A.I.N Marheni, I made Sutama. 2014. Kontribusi Kemampua Verbal dan Kemampuan Membaca Pemahaman terhadap Prestasi Belajar Siswa dalam Menyelesaikan Soal Cerita Pada Pelajaran Matematika. Volume 4. http:// download.portalgaruda.org/article. Di akses 03 Juni 2016

Oszoy, Gokhan dkk. 2015. Evaluation of student's Mathematical Problem Solving Skill in Relation to Their Reading Levels. Volume 8. http://www.iejee.com. Di akses 26 Juli 2016

Somadayo, Samsu. 2011. Strategi dan Teknik Pembelajaran Membaca. Yogyakarta: Graha IImu

Suherman, Erman dkk. 2003. Strategi Pembelajaran Matematika Kontemporer. Bandung: Jica

Wijaya, Ariyadi. 2012. Pendidikan Matematika Realistik : Suatu Alternatif Pendekatan Pembelajaran Matematika. Yogyakarta : Graha IImu

Windari F, Dwina F, Suherman. 2014. Meningkatkan Kemampuan Pemecahan Masalah Matematika Siswa Kelas VIII SMPN 8 Padang Tahun Pelajaran 2014/2014 dengan Menggunakan Strategi Pembelajaran Inkuiri. Jurnal Pendidikan Matematika. Volume 3. Nomor 2. hIm 25 - 28

Zhang j, Fan X, Cheung SK, Meng Y, Cai Z, Hu BY. 2017. The Role of Early Language Abilities on Math SkillsAmong Chinese Children. Plos One 12(7): e0181074. https://doi.org/10.1371/journal.pone.0181074 